\title{
Negotiating recreational access under asymmetrical power relations: the case of inland waterways in England
}

\author{
Andrew Church,** Paul Gilchrist* \& Neil Ravenscroft* \\ **School of Environment \& *Chelsea School, University of Brighton
}

Running Head: Negotiating recreational access

Contact:

Dr Neil Ravenscroft, Chelsea School, University of Brighton, Trevin Towers, Gaudick Road, Eastbourne BN20 7SP, N.Ravenscroft@brighton.ac.uk

\begin{abstract}
This paper addresses recreational conflict between anglers and boaters in England. While recognising that interpersonal conflicts between individual anglers and boaters exist much as they do in other countries, the paper argues that the position in England is mediated through complex land and property rights that position the stakeholders asymmetrically, as legal rights holders (anglers) and moral rights claimants (boaters). Under this scenario, negotiated attempts to increase access for boaters are interpreted not primarily as a means of addressing the asymmetry, but as a mechanism for underwriting the dominant property power of the anglers. Using data collected from focus groups involving stakeholders the paper suggests that, in cases where recreational access to natural resources is mediated through socio-political institutions such as law, weaker stakeholders have very limited options in terms of the legal or social mechanisms through which the can pursue or assert their claims.
\end{abstract}

Key Words: anglers; boaters; England; property rights; recreational conflict;

\section{Introduction}

There is an established literature on conflict in recreational settings, largely understood in terms of the difficulties encountered by different types of uses (and users) of the same resource (see Driver and Bassett, 1975; Jacob \& Schreyer, 1980; 
Gramann and Burdge, 1981; Jackson and Wong, 1982; Owens, 1985; Ruddell and Gramann, 1994; Watson, Niccolucci and Williams, 1994; Ramthun, 1995; Schneider \& Hammitt, 1995; Vaske, Donnelly, Wittman \& Laidlaw, 1995; Ewert, Dieser \& Voight, 1999). Most of these studies have examined recreational conflict through the medium of competition between user groups, leading Ewert, et al, to define recreational conflict as:

A condition that exists when one person, or group of people, experience or perceive an interference of goals or the likelihood of incompatible goals, as the result of another person's or group's actions, threat of action, or personal/group attributes (1999: p. 337).

Recreational conflict is thus constructed in social or psychological terms as the outcome of interpersonal or inter-group relationships largely distinct from the context in which those relationships (and thus the conflicts) occur. This is despite the very distinctive resource settings in which most recreational conflicts take place. Yet, as Ravenscroft, Uzzell and Leach (2002) have argued with respect to non-motorised shared use trails, it can be the resource itself that creates the setting in which recreational conflict is experienced, even if the conflict itself is still redolent of Ewert, et al's (1999) user-based construction.

Perhaps the most extreme case of resources creating the setting for conflict to occur concerns public access to or across private property, which usually involves one party claiming a higher right on the basis of their ownership of a superior legal interest in the property (see, for example, Curry, 1994; Ravenscroft, 1998; Mongeau, 2001, 2003; Parker, 2002). In such asymmetrical cases, perceptions take on an added layer of complexity, relating not only to legal and moral questions of right, but also to practical questions about the enforceability of these rights in different contexts (Curry, 
2001; Kaltenborn, Haaland \& Sandell, 2001; McIntyre, Jenkins \& Booth, 2001; Elmendorf, 2003). Thus understanding how property rights influence and impact upon recreational access and conflict over natural resources is an increasingly important research agenda.

Although there is little sustained research on the property related aspects of recreational conflict (Mongeau, 2001, 2003), an acute case exists in England, relating to recreational access along inland rivers and waterways. In some countries rivers of a certain size are enshrined in law as public rights of way and conflict arises from the sharing of the public resource (O'Riordan and Paget 1978). England is one of a number of countries where this is not the case. In England, a public right of navigation $^{\mathrm{i}}$ exists on estuaries, tidal waters, canals and a few major rivers such as the Thames. The majority of non-tidal waterways, however, are privately owned with no public right of navigation, making it extremely difficult for canoeists ${ }^{\mathrm{ii}}$ and other boaters to pursue their sports (Foster, 1985; Countryside Agency, Forestry Commission, Environment Agency \& English Nature, 2000; Countryside Agency, 2004). In contrast, access to watersides for fishing and the exercise of rights to fish are well established in property law (House of Commons Select Committee on Environment, Transport and Regional Affairs, 2001), with the owners of these rights having a vested interest in using their legal rights to prevent any boating activity that might hinder their enjoyment of the fishing, whether or not any conflict is likely to occuriii

Unlike Ewert, et al's, (1999) goal difference thesis, therefore, this propertybased conflict is largely understood and articulated through discourses of legallyenforceable rights (see Foster, 1985) and morally-based claims that compete for absolute primacy, regardless of the level of interpersonal conflict that actually exists. 
However, the asymmetrical legitimacy of the discourses is such that anglers merely have to establish their legal right of occupation, in contradistinction to the canoeists, who have to establish a moral claim so compelling that either it leads to anglers willingly agreeing to share river space or it becomes (eventually) enshrined in law as a higher right than (mere) occupation of property. Through an analysis of these discourses, undertaken through focus groups with relevant stakeholder groups, this paper seeks to address the issue of rights-based recreational conflict, with a view to examining the extent to which the weaker party to an asymmetrical socio-political relationship has the power to negotiate improved terms or conditions. The subject of the research was a proposal (Countryside Agency 2004) to improve recreational (canoe) access to four rivers in England - the Rivers Teme, Mersey, Wear and Waveney (see Figure 1). This proposal, promoted by a national government body, involved exploring the feasibility of using negotiated voluntary agreements rather than legislative change to provide more river space for canoeing.

\section{Figure 1 About here}

\section{Land, Property and the Right of Navigation}

In English law, 'land' generally includes all that lies under or above its surface, as well as the surface itself (Law of Property Act, 1925). In the case of a nontidal river, ownership of the land lying beneath the water normally determines the broad uses of the water, even if it does not imply the right to use or dispose of the water itself. Thus, the owner of the controlling interest in the land adjacent to the water normally owns the right to control access to and on the water, subject to any public rights of access or navigation (Telling \& Foster, 1978; Telling \& Smith, 1985).

Ownership, in English law, is broadly viewed in Lockean terms as control over a bundle of rights, the owner of which has the most extensive form of control 
over property known to the law (Becker, 1977; Denman, 1978; Gray, 1993; Munton, 1994; Parker, 2002). Out of this bundle of rights, the owner can carve lesser interests, such as leases and licences, which allow other people some access to and rights over the property (Law of Property Act 1925). While this devolution of rights works well for more static occupational uses of individual properties (including fishing leases and licences), it is not suited to the physical practice of navigation (movement) along waterways, where the legal interest being sought is no more than a temporary right of passage. Whereas the Highways Acts have been enacted to facilitate such movement on land, there is no equivalent on watercourses, meaning that those wishing to move along waterways where no public right of navigation exists face the daunting task of seeking permission from every individual landowner (Telling and Smith, 1985). This is the legal position with respect to more than $80 \%$ of the principal rivers in England (University of Brighton Consortium 2001).

Despite the difficulties facing recreational users of inland waterways, a recent government report, the Salmon and Freshwater Fisheries Review (Ministry of Agriculture, Fisheries and Food, 2000), concluded that the ownership of fishing rights in particular and private rights of access to watersides in general are longstanding rights under English law. This has been supported in principle by a House of Commons Advisory Committee (House of Commons Select Committee on Environment, Transport and Regional Affairs 2001), which felt that any relaxation of this position would be detrimental to the interests of anglers and landowners.

As a result, the current system of interests in land and water suits those - such as angling clubs - who seek to occupy specific parcels of land for specific purposes, at the expense of those who merely seek to move along water. In apparent recognition of this anomaly, Government has sought to increase access to and along water for those 
without appropriate rights, such as canoeists, through voluntary agreements that involve sharing water spaces (Angling and Canoeing Liaison Group, 1999). However, the 'sharing' is very often temporally zoned, with the owner of the superior land rights (usually the anglers) dictating the terms. In 2001 there were 51 recognised voluntary access agreements for canoeing in England and Wales, although only 5 of these were open all year (University of Brighton Consortium, 2001).

For these agreements, the construct of 'voluntarism' is asymmetrical, with the rights owners able to determine the nature of the agreement to an extent not available to the other party. In addition, since land rights (and angling requirements) are spatially fixed and canoeing is essentially dynamic, the two do not often mesh in ways appropriate for conventional approaches to access agreements based on land rights (see Feist, 1978). Not surprisingly, there is pressure from canoeists for change (British Canoe Union, 2003) and government bodies have also pledged to develop initiatives (but not legislation) that can improve the level of access to water (Countryside Agency 2004). There is also a variety of national and local forums and measures that aim to alleviate the conflict between inland water users (Angling and Canoeing Liaison Group 1999). However, it is not clear to what extent the weaker party to the relationship has the ability to mitigate exclusion through rights-based negotiation and mediation. The next section of the paper addresses this question, in seeking to explore the causes of the long running conflict and to assess the role played by property rights and related discourses in constructing and, potentially, mitigating the effects of recreational conflicts over natural resources.

\section{Data Collection}

Data for this research have been drawn from two principal sources: documents and articles published by angling and canoeing representative organisations; and focus 
groups undertaken as part of in-depth case studies of four rivers in England, in the period 2003-2005. The studies focussed on certain stretches of each of the rivers where conflicts or access issues were particularly pronounced (see Table 1).

\section{TABLE 1 ABOUT HERE}

Ten focus groups were undertaken, half comprising canoeists and the other half comprising landowners and anglers. Eight were regional in that they focussed on, and took place near, the rivers (one each for canoeing and angling/landowning), while the remaining two took place in London and comprised representatives from national canoeing and angling bodies including the British Canoe Union (BCU), the Salmon and Trout Association (STA), the National Federation of Anglers (NFA) and National Association of Fisheries and Angling Consultatives (NAFAC). The eight river-based regional focus groups each had approximately ten participants, all of whom were recruited from local clubs and representative groups. The London focus groups comprised five people (angling) and six people (canoeing), with all the participants being post-holders in national representative organisations. The key themes developed in the London focus groups concerned the perceived causes of and potential solutions to conflict, while the regional focus groups were used to apply these themes to the specific case studies. The focus groups were tape-recorded and the contents analysed to identify the key themes (London) and the applied sub-themes (regions) concerning access to water, voluntary agreements and the experience of conflict.

\section{Findings - the nature of conflict}

Canoe representatives at the London meeting based their claims on the BCU access strategy for England, which has committed the BCU to pursuing voluntary agreements in the short term and new access legislation in the longer term: 
The BCU is committed to securing a fair and secure share of access to a variety of inland water forms across England for canoeing: over the next three years by supporting the government access negotiation demonstration project led by the Countryside Agency; over the longer term by promoting primary legislation for a right of navigation for nonmechanically propelled craft to inland waters (BCU 2003 p.1).

Much of the debate at the London and regional meetings centred on canoeists seeking to substantiate this statement, especially the 'moral' claim to a fair share. For example, it was argued that:

We want fair and secure agreements that give us access to rivers 365 days per year ... (canoe representative, London)

40 years ago, canoeists could paddle anywhere without let or hindrance ... they can't any more (canoeist, River Wear)

Paddlers want access 12 months per year, reflecting different types of canoeing, different craft and different water conditions. However, this does not have to be exclusive access: paddlers are happy to share with anglers and other water users ... they also accept access on designated days of the week (canoe representative, London)

However, there were also critics of this stance, both within the groups and more generally. For example, a participant at a regional group made the point that: 
I am now 55 years old; for many years I have listened to people telling me that a voluntary approach to access will work. I am still waiting and time is running out (canoeist, River Wear)

One member of the BCU participating in the London group claimed that access agreements had failed to deliver significant improvements and that in negotiating with rights holders there is:

... clearly a balance to be struck. We just feel at the moment that we are not even making any sort of steps to getting to that balance (canoe representative, London)

In this situation conflicts over access in certain areas has become quite intense. One game angling representative noted that parts of rivers in Wales with white water suitable for canoe slalom had become a 'boiling cauldron of conflict' (angling representative, London). This was confirmed by the attitudes of some anglers in the regional meetings:

... canoeists will be bricked [have bricks thrown at them] if they come on to my water (angler, River Wear)

... what fishermen don't want is boats coming close ... One or two boats: no problem; but a crocodile of $35 ?$... there will be blood (angler, River Waveney)

Clearly in keeping with the claims of writing on recreational conflict (Schneider and Hammitt 1995) differences in social values imbue some of the positions and attitudes adopted by users and user representatives. For example, both anglers and canoeists often seek to present themselves as having superior environmental values. Anglers at 
the national and regional meetings particularly emphasised an environmental discourse to support their claims to property rights:

We are conservationists and environmentalists, not just extractors; the paddlers are consumerists ... (angling representative, London)

Canoes damage a very delicate ecosystem and can lead to a reduction in invertebrates ... a lot of the problem is silting caused by canoes ... canoeists trample all over the banks and break the fences, letting cattle get into the river which causes the silting (angler, River Teme)

In some cases, stakeholders related this to their particular river:

The problem is that small rivers ... will be damaged by canoes; they are hard objects that will cut away the banks, damage the beds ... canoes are here to stay, but we need to educate canoeists ... they don't care for the environment ... rivers don't have time to recover from damage caused by careless canoeists (angling representative, River Teme)

Such a view is strongly disputed in numerous BCU publications that stress the contribution that canoeists make to conserving inland aquatic environments and the fact that when properly used, kayaks and canoes 'leave no trace of their passing' (Stott 1999). This was echoed by canoeists and some landowners in the regional meetings:

Unlike fishing, canoes move along the water leaving no trace of their passage and no damage to property ... (canoeist, River Wear) 
The anglers complain about the canoeists damaging the environment

... but they seem completely unaware of the damage that they do to our

[river] banks (landowner, River Wear)

These competing claims over the environmental impacts of canoeing and angling clearly indicate how differences in social values and indeed moral standpoints structure the debates over conflict. They also indicate that the current conflict cannot be understood by simply looking at events on particular rivers. Instead, an examination is required of the discourses and attitudes expressed not only by individual water users but also, and perhaps more importantly, by the organisations that claim to represent users. The views and arguments most commonly utilised in the competing discourses provide ample evidence of how the conflicts on inland waters in the England are constructed by a complex set of power relations over land rights that have developed over a long period of time.

\section{Findings - power and property rights}

In 2001 the Salmon and Trout Association paid for an advertisement to appear in a number of angling magazines as part of a strategy for gathering support to maintain current arrangements over access to inland water. The advertisement, entitled "No 'right to roam' for water', set out the following reasons why angling organisations felt that their current ability to control recreational user access to many inland rivers is a defensible situation:

Access is negotiated on a voluntary basis in a system which has evolved over 150 years. It is also a system that works well because it protects all the participants - riparian owners, anglers and the environment. The same negotiating arrangements are available to canoeists but the principal reason why angling has been so successful 
in obtaining access is that we are prepared to pay (The Salmon and Trout Association 2001 p.17).

The advertisement encapsulates the three key elements of the discourse used by angling organisations to justify the current access arrangements, despite the conflicts that arise. First, access arrangements are rooted in a long-standing legal system that protects owners but which can be used by all those who wish to access water. Second, it is argued by anglers that this is a justifiable system since it is based on voluntarism within the national system of property rights rather than occurring within imposed legislation drawn up specifically for inland water sports. The third key element of the legitimising discourse used by angling stakeholders is that current access arrangements for angling are based on financial transactions. For many of the angling representatives in focus groups the issue of payment was highlighted as perhaps the key source of conflict. Anglers in Britain pay a rod license to the national Environment Agency, which allows them to own a rod. They will also pay to access water through club membership fees, permits or day tickets. One participant claimed that:

Angling is an expensive sport, we pay our rod licence, we pay our rates and taxes as we all do, but we pay the rod license, we pay the permit, and then we've got all our tackle which is discounted because that's the same on both sides [i.e. canoeists pay for their equipment as well]. But we pay to the Environment Agency and that is perhaps the biggest bone of contention with anglers because canoeists do not pay. If there was a system like boat licensing it might undermine the angling case (angler, River Mersey). 
In this situation current access arrangements are seen as justified because they adhere to a traditional legal system and a set of social values that stress the importance of market forces and the benefits of voluntarism. Angling organisations regularly highlight the role of volunteers in negotiating access. The National Association of Fisheries and Angling Consultatives (NAFAC) is a national representative body and argues that angling bodies nationally and locally gain significant legitimacy as they rely on volunteers working within the legal system: ... angling is managed locally, mostly by volunteers who often have very few formal qualifications ... The acquisition of fishing rights for angling is very largely the result of anglers learning about and working within the legal framework on their own initiative ... other interests seeking access to waterspace often deliberately ignore the framework, using complexity as an excuse (NAFAC 2003 p.5).

Furthermore, the demands of canoeists for access to currently unavailable water are constructed as unreasonable unless they are progressed through the current legal framework and involve some form of payment:

Access agreements with landowners [for canoeing] could ... be sought in the way that angling clubs do: by approaching the people concerned directly and renting or buying the right to use the land and water (angling representative, River Wear).

Landowners should have the right to charge for the use of their land ... experience suggests that they [canoeists] are usually unwilling to pay for access (landowner, River Wear). 
Not surprisingly, organisations representing canoeing have responded to these arguments as part of their case for changes to current arrangements. The BCU access strategy contains a stated position on payment:

Where a landowner allows canoeists access to land for the dedicated use of a short stretch of water, usually a rapid, this constitutes 'occupation'. The question of any payment is between the owner and the visiting canoeist bearing in mind the various market factors. For passage along a stretch of water (i.e. touring) payment is not considered appropriate. This position totally concurs with the government white paper leading to the Countryside and Rights of Way Act that made it clear that there would be no question of payment for access to the countryside itself (BCU, 2003 p.3).

This statement stresses that canoeists can work within a voluntary system that involves payment in some circumstances but for touring activity the BCU seeks to justify its position by reference to the intentions of government policy on access to the countryside as set out in the Countryside and Rights of Way Act 2000 which extended public access to certain types of land but did not apply to inland water. For others, however, even this goes too far:

We should not get drawn into the parallel 'we pay, why don't they?' scenario ... this is not a reasonable comparison ... (canoeing representative, London)

These competing discourses mutually reflect and construct a set of power relations in which anglers and riparian owners largely dictate access for canoeists on rivers where there is no public right of navigation. In a situation of asymmetrical power relations based on a combination of voluntaristic negotiations, legal property rights 
and financial transactions, those who are advantaged by the current structures are in a strong position to determine the nature of conflict resolution and any change to access arrangements such as through voluntary agreements. Many angling organisations quite openly acknowledged this relationship in their negotiations with canoeists, as one angling representative commenting upon with respect to a regional process of conflict resolution with canoeists:

We would have continued the dialogue that started in 1996. We would of. I don't want to apportion blame. Had we been wanting to do it we could have pursued it but we [anglers] were giving rather than the takers [canoeists] so it was up to them to pursue it rather than us (angling representative, London).

\section{Findings - rights and negotiating voluntary agreements}

The nature of conflict and growing political pressure for canoeists to have more access to water (Countryside Agency, 2004) has meant that many angling organisations are willing to contemplate limited changes to access arrangements. In the focus groups, however, many angling representatives made it clear that change should be on their terms and usually be in their interests. For example, a number of angling organisations were willing to 'trade' water with canoeists so that canoeing would be allowed by voluntary agreements on some rivers providing local canoe clubs agreed never to use other rivers where the fishing conditions were of a much higher quality. Others were willing to contemplate new arrangements that allowed canoeists access in very specified circumstances, often when anglers would not wish to be present. One angling representative felt canoeing access for specified events was reasonable for a highly desirable white water river, but that this should occur only when water levels were high and angling would not be feasible: 
In the case of the xxx river they have a limited period and limited events. I think they confine them to about 10 events so they don't allow individual canoeing but events are ok and that's as I see it too. But basically if we could turn the thing on its head and ask if canoeists had bought the river would they allow us free angling and once you think of it like that it's a different thing. We have paid somehow or other for our fishing and it is now very valuable but we are sticking to it. That's a big investment to let anyone on willy nilly. At the same time I'm one of those who thinks if we are not using it why couldn't someone else have a go? (angler, River Teme).

For others, particularly landowners and farmers, the balance between angling and canoeing is much more straightforward:

The issue is one of value-added for anglers, landowners and canoeists, who all need to gain something from the [access] agreements, if they are to work (landowner representative, River Wear).

Many canoeists find tightly controlled voluntary access arrangements very unsatisfactory since they fail to deliver a significant increase in canoeing opportunities. For example, the Upper Dart river in south west England provides a good mix of water types including some white water but is only accessible through a voluntary agreement for 8 weekends a year and only 30 canoes are allowed each day, which requires booking by clubs up to one year in advance (University of Brighton Consortium, 2001). For angling organisations this agreement is viewed very differently because it is not only restrictive but delivers gains in their interest. The Director of the Salmon and Trout Association claimed that: 
It (access agreements) can work, of course, as has been shown on the Dart in Devon, where compromise allows canoeists a run of the river outside the main fishing season, whilst they agree to stay clear of sensitive spawning and juvenile areas, and even contribute funds to the management and conservation pot (Knight 2003).

Whilst some anglers are willing to contemplate actions that provide canoeists with more access, others maybe less interested since the combination of asymmetric power relations provides little incentive to change. As one national representative noted:

I was trying to push my own association. But my own association never saw a great need for it because as far as they were concerned canoeists were trespassing and it's up to them to stop. I didn't believe that and I believed it should be more open (angling representative, London).

As some of the angler claims highlight, it is erroneous to view the debates and the conflict as entirely structural: all anglers versus all canoeists. While there is a general level of antipathy between the groups, many anglers and canoeists pointed out that their differences are often minor and always nuanced:

... the majority of paddlers are informal recreationists to whom the politics of access is largely irrelevant. Access to and along water is more important than the actual rights being passed over ... (canoeing representative, London).

I think to be fair that when any angler sees kids from the local youth club canoe past them they think nothing about it. It doesn't happen too much and they are our own (angler, River Wear) 
What this last quote indicates is that context is highly important to the protagonists: a few canoes paddled by 'local youth' during pleasure fishing are an entirely different prospect from the fear of a lot of 'outsiders' ruining match fishing. Indeed, some canoeists make use of a number of rivers in England without public rights of navigation or voluntary agreements because they are 'known locals' and landowners have either given verbal permission or chosen to ignore their presence. Many landowners or anglers have strong reservations about turning such arrangements into a formal voluntary agreement. On the river Waveney, for example, a local canoeing club had habitually used the river with the verbal permission of only certain landowners. Anglers expressed the following concerns about formalising this into a voluntary agreement:

We are all very cagey - especially about the thin end of the wedge once canoes get agreement, what about rowing boats, motorboats ... once there are a few canoes there will be a lot ... so anglers are wary of agreeing to or giving an amber light to a process that could lead to uncontrolled access ... (angler, River Waveney)

Faced with these fears, which are congruent with those found by other research into conflict between anglers and boaters (Shelby, Bregenzer \& Johnson, 1988), anglers and landowners in England (and Wales) have at their disposal the potential to deploy their property power to assert their dominance. In this sense, their property power acts as a hegemonic force: the canoeists cannot deny the legitimacy of property rights if they are seeking rights-based agreements to canoe, yet by recognising those rights their actions underwrite the superior rights claims of the anglers. 


\section{Discussion and Conclusions}

Clearly, the recreational conflicts on England's rivers cannot be fully understood by the same social psychological and social values based explanations that have been identified in other research (Schneider and Hammitt 1995, Vaske et. al.1995). This is not to deny the legitimacy of this work, nor to claim that both anglers and canoeists in England do not experience some of the same emotions. However, it is clear that, in the English context, the conflict has its roots in a system of hegemonic power structures based on assumed 'rights', voluntaristic traditions and financial payments for property (Ravenscroft, 1995). Often voluntarism is viewed as a positive dimension to sporting culture and institutions (Puttnam 2000; Taylor, 2004). In the case of sport and recreation on English inland water, however, voluntarism is one factor contributing to a system of power relations that significantly advantages one group of users over another.

It is this legal asymmetry that makes the case of anglers and boaters both interesting and difficult to resolve. While recent initiatives (Countryside and Rights of Way Act 2000) may have introduced a limited statutory public right of access on foot to some land, it remains the general case that access to land (and water) is largely a function of property power (Ravenscroft, 1995; Shoard 1999; Parker \& Ravenscroft, 2001). Since it is generally assumed that land is non-portable and use is site-specific, there has been little need in law to consider the implications of this property power in cases where the demand is for linear passage (noting, in England, that passage over land has long been governed by highways rather than land law). Yet it is here that the very solidity of the law demonstrates admirably its primary function of exclusion.

The landowning and fishing interests have long argued that nothing prevents paddlers from acquiring land rights. This is certainly the case - where they become 
available. However, the market value of passage along water - if such a thing exists is likely to be considerably less than the value of the fishing rights, meaning that paddlers would be forced into the position of acquiring rights that they do not want in order to protect the lesser rights that they require. Not only is this inefficient, but it is also a very expensive means of gaining access. Regardless of this, the non-portability of land also precludes paddlers from achieving access through purchase, since it is highly unlikely that a long and continuous stretch of water will become available, even over time - and that they could afford to out-bid other potential purchasers if it did.

Thus, by annexing both property power and the rhetoric of the market, anglers are able to mount a 'common-sense' defence to paddler claims of moral rights of access to inland waters in England, safe in the knowledge that the paddlers can neither undermine the institution of property, nor utilise the market to protect their claims. In this situation, the paddlers are left in the untenable position of attempting simultaneously to negotiate voluntary access agreements (in the process reinforcing the hegemony of property) and to claim universal access rights (by challenging the very hegemony of property that they simultaneously seek to underpin), knowing in the process that success - even minor - in one arena will undermine their claims in the other. They are equally aware of the fragility of both institutions: voluntary agreements that become too well-known and successful could undermine their claims about responsible access and environmental awareness; while agreements that are underused undermine their claims about the need for access. Similarly, to demonstrate the need for a statutory solution there is a requirement not to abuse current rights, which again means failing to demonstrate the demand for access. 
As a result, the angler-paddler conflicts experienced in England are significantly different from those experienced in some other countries where legal rights to navigate on rivers are different (accepting, of course, that recreational access in many countries is predicated at least in part on 'assumed' rights; see Curry, 2004). Rather than concepts such as goal difference being of primary important in understanding (and mediating) conflicts, the position in England revolves around rights: while there may be interpersonal conflicts, the asymmetrical underlying situation exists regardless of where and when different users try to share space. It is the very construct of 'sharing' that causes the conflict, implying as it does that those who have legitimately acquired legal rights to property are expected to devolve some of those rights to others who have not engaged in the market and thus have no legal means of access. As such, the principal answer to the research question posed is that the ability of the weaker party to mitigate the power of superior rights is negligible. Rather, as the findings have indicated, the actions of the weaker party within the hegemony of property rights can end up legitimating the concentration and deployment of those rights in the hands of static land-based interests.

\section{References}

Angling and Canoeing Liaison Group (1999) Agreeing Access for Canoeing. Bristol, England: Environment Agency.

Becker, L. (1977) Property rights: philosophic foundations. London, England: Routledge.

British Canoe Union (2003) Access Strategy: England. Nottingham, England: BCU. Countryside Agency, Forestry Commission, Environment Agency \& English Nature (2000) Improving access to woods, watersides and the coast. A joint report to Government on the options for change. Publication CA 33. Cheltenham, England: Countryside Agency. 
Countryside Agency (2004) A feasibility study on improving access for canoeing by voluntary agreement. Research Notes, CRN 79, Cheltenham, England: Countryside Agency.

Countryside and Rights of Way Act 2000 (2000 Chapter 37)

Curry, N.R. (1994) Countryside recreation, access and land use planning. London, England: E \& F N Spon.

Curry, N. (2001) Rights of access to land for outdoor recreation in New Zealand: dilemmas concerning justice and equity. Journal of Rural Studies 17: 409-419.

Curry, N.R. (2004) The divergence and coalescence of public outdoor recreation values in New Zealand and England: an interplay between rights and markets. Leisure Studies 23(3): 205-223.

Denman, D. (1978) The place of property. Berkhamstead, England: Geo Books.

Driver, B.L. and Bassett, J. (1975) Defining conflict among river users: a case study of Michigan's Au Sable River. Naturalist 26: 19-23.

Elmendorf, C.S. (2003) Ideas, incentives, gifts and governance: Toward conservation stewardship of private land, in cultural and psychological perspective. University of Illinois Law Review 2: 423-505.

Ewert, A.W., Dieser, R.B. and Voight, A. (1999) Conflict and the recreational experience. Pp 335-345 in Jackson, E.L. and Burton, T.L. (eds) Leisure studies: prospects for the twenty-first century. State College, PA: Venture Publishing, Inc.

Feist, M.J. (1978) A Study of Management Agreements. Publication CCP 114. Cheltenham, England: Countryside Commission.

Foster, S.E. (1985) Inland waterways: legal aspects of public access and enjoyment. Journal of Planning and Environment Law, July, pp 440-460. 
Gramann, J.H. and Burdge, R. (1981) The effect of recreation goals on conflict perception: the case of water skiers and fishermen. Journal of Leisure Research 13, 15-27.

Gray, K. (1993) Elements of land law, $2^{\text {nd }}$ edition. London, England: Butterworths. House of Commons Select Committee on Environment, Transport and Regional Affairs (2001) Fourth report: inland waterways. London, England: House of Commons Papers.

Jackson, E.L. \& Wong, R. (1982) Perceived conflict between urban cross-country skiers and snowmobilers in Alberta. Journal of Leisure Research 14, 47-62.

Jacob, G.R. \& Schreyer, R. (1980) Conflict in outdoor recreation: a theoretical perspective. Journal of Leisure Research 12, 368-380.

Kaltenborn, B.P., Haaland, H. and Sandell, S. (2001) The public right to access some challeneges to sustainable tourism development in Scandinavia. Journal of Sustainable Tourism 9: 417-433.

Knight, P. (2003) A Question of Access. Salmon and Trout, February, 12.

Law of Property Act 1925 (15 Geo. 5, c. 20.)

McIntyre, N., Jenkins, J. and Booth, K. (2001) Global influences on access: The changing face of access to public conservation lands in New Zealand. Journal of Sustainable Tourism 9: 434-450.

Ministry of Agriculture, Fisheries and Food (2000) The salmon and freshwater fisheries review. London, England: Ministry of Agriculture, Fisheries and Food.

Mongeau, D. (2001) Public access to the beach: a selective bibliography. Reference Services Review 29(1): 81-88. 
Mongeau, D. (2003) Coastal access and public policy: a selective annotated bibliography. Reference Services Review 31(4): 374-384.

Munton, R. (1994) Rural accumulation and property rights: sustaining the means. Paper given at the Institute of British Geographers' Conference, University of Nottingham, England, January 1994.

National Association of Fisheries and Angling Consultatives (2003) Proposals for Trial Access Projects. Unpublished document prepared on behalf of the National Angling Alliance. Kings Lynn, England: NAFAC.

O'Riordan, T. and Paget, G. (1978) Sharing rivers and canals. A study of the views of coarse anglers and boat users on selected waterways. Study 16. London, England: Sports Council.

Owens, P.L. (1985) Conflict as a social interaction process in environment and behaviour research: the example of leisure and recreation research. Journal of Environmental Psychology 5: 243-259.

Parker, G. (2002) Citizenships, contingency and the countryside. London, England: Routledge.

Parker, G. and Ravenscroft, N. (2001) Land, rights and the gift: the Countryside and Rights of Way Act 2000 and the negotiation of citizenship. Sociologia Ruralis 41(4): 381-398.

Puttnam, R. (2000) Bowling alone. New York, NY: Simon \& Schuster.

Ramthun, R. (1995) Factors in user group conflict between hikers and mountain bikers. Leisure Sciences 17: 159-169.

Ravenscroft, N. (1995) Recreational access to the countryside of England and Wales: popular leisure as the legitimation of private property. Journal of Property Research 12: 63-74 
Ravenscroft, N. (1998) Rights, citizenship and access to the countryside. Space \& Polity 2(1): 33-49.

Ravenscroft, N., Uzzell, D. and Leach, R. (2002) Danger ahead? The impact of fear of crime on people's recreational use of nonmotorised shared-use routes. Environment and Planning C: Government and Policy 20(5): 741-756.

Ruddell, E.J. \& Gramann, J.H. (1994) Goal orientation, norms and noise-induced conflict among recreation area users. Leisure Sciences 16, 93-104.

Schneider, I.E. \& Hammitt, W.E. (1995) Visitor response to outdoor recreation conflict: a conceptual approach. Leisure Sciences 17, 223-234.

Shelby, B., Bregenzer, H. \& Johnson, R. (1988) Displacement and product shift: empirical evidence from two Oregon rivers. Journal of Leisure Research 20: 274-288.

Shoard, M. (1999) A right to roam. London, England: Grafton.

Stott, T. (1999) The River and Waterway Environment for Small Boat Users. An Environmental Guide for Recreational Users of Rivers and Inland Waterways. Nottingham, England: British Canoe Union.

Taylor, P. (2004) Driving up participation: sport and volunteering. Pp 101-108 in Sport England (2004) Driving up participation: the challenge for sport. London, England: Sport England.

Telling, A.E. and Foster, S.E. (1978) The Public Right of Navigation. Volume 1: General Principles. Research and Development Project Report PFA 12. Nottingham, England: Severn-Trent Water Authority.

Telling, A.E. and Smith, R. (1985) The Public Right of Navigation. A Report to the Sports Council and the Water Space Amenity Commission. Study 27. London, England: Sports Council. 
The Salmon and Trout Association (2001). No "right to roam" for water. Hooked Magazine Advertisement, May, 17.

University of Brighton Consortium (2001) Water-based Sport and Recreation: The

Facts. Bristol, England: Department of Environment, Food and Rural Affairs. (www.defra.gov.uk/wildlife-countryside/resprog/findings/watersport.pdf)

Vaske, J.J., Donnelly, M.P., Wittman, K. \& Laidlaw, S. (1995) Interpersonal versus social values conflict. Leisure Sciences 17, 205-222.

Watson, A.E., Niccolucci, M.J. \& Williams, D.R. (1994) The nature of conflict between hikers and recreational stock users in the John Muir Wilderness. Journal of Leisure Research 26, 372-385.

\footnotetext{
${ }^{\mathrm{i}}$ A Public Right of Navigation is a legal term denoting the right at law for all watercraft to use a given waterway, even if the banks and bed of the waterway are privately owned and the use would otherwise constitute trespass. Such a term does not, therefore, refer to the practise of navigating along a waterway.

${ }^{\text {ii } I n ~ E n g l a n d, ~ t h e ~ t e r m ~ c a n o e ~ i s ~ a ~ g e n e r i c ~ d e s c r i p t i o n ~ f o r ~ o p e n ~ c a n o e s ~ a n d ~ k a y a k s . ~}$

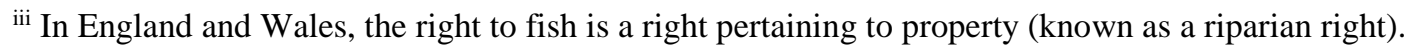

The person who owns the legal interest in the banks and beds of rivers and lakes also owns the riparian rights and thus can determine whether or not fishing takes place, who has the right to fish, and to what extent this right is exercised to the exclusion of other uses such as canoeing and kayaking.
} 